\title{
CROWDFUNDING SEBAGAI PEMAKNAAN ENERGI GOTONG ROYONG TERBARUKAN
}

\author{
Oleh : \\ Maulana Irfan ${ }^{1}$ \\ 1. Mahasiswa Program Doktor Kesejahteraan Sosial FISIP Universitas Padjadjaran \\ Email: \\ mirfan@gmail.com
}

\begin{abstract}
Abstrak
Nilai-nilai gotong royong sebagai budaya Indonesia yang merupakan bentuk solidaritas sosial masyarakat diduga kian samar atau bahkan menghilang di kehidupan saat ini. Ini terjadi seiring kencangnya laju globalisasi. Perubahan yang terjadi diikuti pula oleh perkembangan teknologi, diantaranya teknologi telekomunikasi berupa handphone. Berawal hanya berfungsi sebagai alat telokomunikasi sederhana hingga sampai pada teknologi smartphone yang memungkinkan pengguna menjelajah jejaring internet yang dikenal dengan istilah media sosial. Keterjangkauan yang luas memberi peluang komunitas netizen berinteraksi antar sesama individu melalui media sosial. Seiring dengan perubahan itu membawa pada perkembangan aspek lainnya, sebagian orang menggunakan sebagai ajang pergaulan semata, sebagian menggunakannya sebagai wadah usaha (e-commerce), bahkan sebagian masyarakat lainnya menggunakan menjadi gerakan sosial. Media sosial dapat menjadi potensi positif dalam membangun perubahan perilaku masyarakat. Gerakan sosial pun dapat memperkuat peran sosial media untuk menyuarakan kesamaan rasa atas ekspresi ketidaknyaman dalam sebuah tatanan pemerintahan yang saat ini terjadi hingga sampai pada membangun kesepakatan membuat kegiatan nyata untuk merealisasikan gerakannya. Beberapa organisasi nirlaba memanfaatkannya melalui jejaring internet dalam melakukan penggalangan dananya, dengan memunculkan proyek dan portofolio. Aktifitas Fundraising melalui jejaring sosial disebut dengan Crowdfunding. Crowdfunding merupakan suatu model pendanaan dengan beberapa aktor yang berperan didalamnya. Semangat kolaborasi tersebut merupakan semangat yang sudah menjadi budaya nusantara, yaitu semangat gotong royong. Konsekuensi perubahan sosial dalam konsep gotong royong ternyata bermetamorforsis dalam media yang berbeda. Esensi gotong royong sebagai tindakan bekerja sama tanpa pamrih tetap tidak hilang. Namun berubah dengan menggunakan cara yang berbeda. Potensi ini dapat menjadi sebuah strategi baru bagi organisasi nirlaba atau organisasi pelayanan sosial dalam membangun jejaring khalayak yang lebih luas. Termasuk didalamnya adalah peran pekerja sosial.
\end{abstract}

Kata Kunci: Gotong royong,Media Sosial, Pekerja Sosial, Fundraising, Crowdfunding

\section{PENDAHULUAN}

Budaya gotong royong sudah melekat dalam karakteristik bangsa Indonesia. Praktik gotong royong telah ada sejak lama di berbagai daerah di Indonesia. Misalnya di pedesaan Jawa yang masih melakukan praktik tradisi gotong royong dalam pembangunan rumah, perkawinan dan kematian. Di Toraja, Sulawesi Selatan, mempraktikkan arisan tenaga, yaitu kegiatan semacam kerja bakti bergilir untuk menggarap sawah atau ladang milik warga lain. Suku Dayak melakukan hal yang sama yang disebut sa'aleant. 
Gotong-royong juga diartikan sebagai bentuk solidaritas sosial. Terbentuk karena adanya bantuan dari pihak lain, untuk kepentingan pribadi ataupun kepentingan kelompok, sehingga di dalamnya terdapat sikap loyal dari setiap warga sebagai satu kesatuan. Dalam hal ini, Parson (1951 : 97 98) mengemukakan,

Loyalty is, as it were, the uninstitutonalized precusor of solidarity, it is the "spilling over" of motivation to conform with the interests or expectations of alter beyond the boundaries of any institutionalized or agreed obligation. Collectivity-orientation on the other hand converts this "propensity" into an institutionalized obligation of the role-expectation. Then whether the actor "feel like it" or not, he is obligated to act in certain ways and risks the application of negative sanctions if he does not.

Dalam artikel hasil penelitian Achsannanda Maulyta Sari ${ }^{1}$, menunjukkan bahwa nilai gotong royong dalam tradisi kerja bakti menjadi karakter bangsa yang diturunkan secara turun-temurun oleh para pendahulu kita yang didalamnya kaya akan nilai edukatif. Akan tetapi dalam kencangnya laju globalisasi saat ini, tradisi kerja bakti yang manfaatnya penting untuk mewariskan nilai luhur bangsa kini menjadi kian samar. Nilai gotong royong seakan pasang surut timbul dalam kehidupan masyarakat sekarang. Maka

\footnotetext{
1 Achsannanda Maulyta Sari ,2015. Artikel. Menegakkan Tradisi Kerja Bakti Sebagai Bentuk
}

diharapkan, tradisi kerja bakti dapat bertahan sebagai salah satu bentuk gotong royong yang dilestarikan. Menegakkan tradisi ini tentu tidak lepas dari peran masyarakatnya dalam membangun rasa kebersamaan, persatuan, dan kepedulian sosial. Sehingga masyarakat terdidik bukan menjadi individualistik, melainkan mementingkan kepentingan umum demi bangsa dan negaranya.

$$
\text { Pasang surut }
$$

bentuk kegotongroyongan ini adalah sebuah konsekuesi atas arus pembangunan yang membawa pada perubahan sosial. Rogers et.al. mengemukakan bahwa perubahan sosial adalah suatu proses yang melahirkan perubahan-perubahan didalam struktur dan fungsi dari suatu sistem kemasyarakatan. Sedangkan Selo Soemarjan dan Soelaeman Soemardi mengemukakan bahwa perubahan sosial diartikan sebagai suatu variasi dari caracara hidup yang telah diterima, baik karena perubahan-peubahan kondisi geografis, kebudayaan material, komposisi penduduk, idiologi, maupun karena adanya difusi atau penemuan-penemuan baru dalam masyarakat tersebut. Soerjono Soekanto merumuskan bahwa perubahan sosial adalah segala perubahan-perubahan pada lembaga-lembaga kemasyarakatan di dalam suatu masyarakat, yang mempengaruhi. 
Seperti diketahui bahwa gotongroyong sebagai bentuk integrasi, banyak dipengaruhi oleh rasa kebersamaan antar warga komunitas yang dilakukan secara sukarela tanpa adanya jaminan berupa upah atau pembayaran dalam bentuk lainnya. Gotong-royong tidak selamanya perlu dibentuk kelembagaan secara resmi melainkan cukup adanya pemberitahuan pada warga komunitas mengenai kegiatan dan waktu pelaksanaannya, kemudian pekerjaan dilaksanakan setelah selesai bubar dengan sendirinya. Adapun keuntungan adanya gotong-royong ini yaitu pekerjaan menjadi mudah dan ringan dibandingkan apabila dilakukan secara perorangan; memperkuat dan mempererat hubungan antar warga komunitas di mana mereka berada bahkan dengan kerabatnya yang telah bertempat tinggal di tempat lain, dan menyatukan seluruh warga komunitas yang terlibat di dalamnya.

Pertanyaan pada pemaknaan gotong royong seiring dengan perkembangan jaman, akankah menjadi memudar atau bahkan hilang? Berikutnya, akankah aktifitas ini masih layak dilakukan di tengah masyarakat yang sudah berubah? Hanya sekedar melakukan kegiatan kerja bakti di tengah komplek perumahan elit perkotaan, mungkinkah ini bisa dilakukan? Terlebih jika ada musibah yang terjadi di lingkungan sekitarnya.

\footnotetext{
Pembangunan yang membawa perubahan sosial pada aspek teknologi diantaranya seolah membangun dunia sendiri
}

bagi lingkungan elitis tertentu membawa pada ruang privacy yang seolah semakin sulit membangun interaksi sosial yang semakin intim. Perkembangan teknologi khususnya di bidang telekomunikasi, menjadi jawaban bagi mereka yang tetap ingin berkomunikasi tanpa harus kehilangan waktu banyak.

Kehadiran media sosial menjadi sebuah sosok dan simbolisasi dunia modern. Media pergaulan beralih pada media yang berbeda. Berawal perkembangan komunikasi Handphone yang memungkinkan berkomunikasi tanpa mengganggu mobilitas tinggi mereka, hingga menuju penggunaan Smartphone yang semakin memungkinkan menggunakan berbagai fungsi media sosial dan berkomunikasi dalam satu genggaman tangan saja.

Terlebih jika melihat data statistic terkait dengan penggunaan internet di Indonesia yang dilansir dalam situs http://www.instink.co.id yang digambarkan sebagai berikut :

\section{Gambar 2.}

\section{Data Pengguna Internet di Indonesia}

Dalam situs tersebut dijelaskan pula pernyataan dari Dirjen Sumber Daya Perangkat Pos dan Informatika (SDPP) .

"Dunia teknologi dan internet berkembang sangat pesat di dunia, tak terkecuali Indonesia. Imbasnya, jumlah 
pengguna internet saat ini semakin besar dan bertambah terus setiap harinya. "Dari 245 juta penduduk Indonesia, pengguna internet di Indonesia mencapai 55 juta orang," ungkap Budi. Hal ini dikemukan oleh Dirjen Sumber Daya Perangkat Pos dan Informatika (SDPP) Kemenkominfo Budi Setiawan. Angka 55 juta pengguna ini berdasarkan data Desember 2011, berarti saat ini tentu jumlah sudah jauh di atas angka tersebut.Jumlah pengguna internet di Indonesia menguasai Asia sebesar 22,4 persen, setelah Jepang. Budi menyebutkan, Indonesia merupakan negara peringkat ketiga di Asia untuk jumlah pengguna internet. Sementara itu, ujar dia, berdasarkan penelitian Nielsen, Indonesia juga masuk sebagai pengguna perangkat mobile tertinggi sebanyak 48 persen, diikuti oleh Thailand dan

Singapura.(www.instink.co.id. diunduh pada tanggal 9 Mei 2015 pukul 18:45)

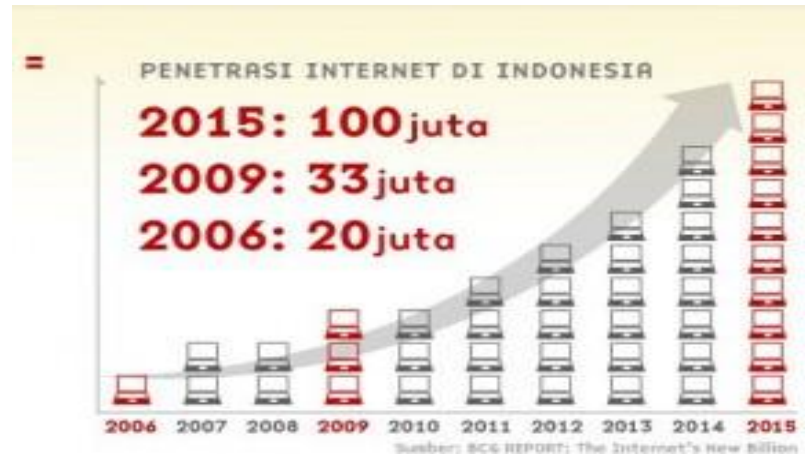

Data tersebut menunjukkan bahwa potensi pengguna internet tersebut dapat menjadi media untuk berkomunikasi baik untuk kepentingan pribadi, bisnis maupun sosial. Menurut Miftachul (2012) lembaga penelitian swasta, Ipsos Indonesia, yang dimuat dalam salah satu artikel di situs Daily Sosial, dikatakan bahwa "Indonesia berada di peringkat teratas dalam penggunaan internet untuk sosial media, termasuk forum dan blog. $83 \%$ pengguna internet Indonesia mengunjungi sosial media saat online. Jumlah ini di atas Argentina (76\%), Rusia(75\%), Afrika Selatan (73\%), Swedia (72\%), Spanyol (71\%), dan Hungaria (70\%). Jika dilihat secara global, 62\% pengguna internet di dunia menggunakan internet untuk sosial media."

Ini membuktikan bahwa perkembangan teknologi sudah tidak bisa dihindari, proses sosial sudah berubah sesuai dengan kondisi kekiniannya. Seiring dengan perubahan itulah tenyata membawa pada perkembangan aspek lainnya. Sementara sebagian orang menggunakan teknologi telekomunikasi dan media sosial sebagai ajang pergaulan semata, sebagian lagi menggunakannya sebagai wadah usaha (ecommerce), bahkan sebagian masyarakat lannya menggunakan menjadi gerakan sosial.

\section{GERAKAN SOSIAL DALAM TEKNOLOGI MEDIA SOSIAL}

Banyak ahli yang melihat gerakan sosial adalah sebuah respon atas sebuah perosalan sosial yang terjadi di kehidupan sosialnya. Gerakan sosial dapat diartikan sebagai tuntutan dari sekumpulan individu ketika menghendaki sebuah perubahan. Charles Tilly, mengungkapkan bahwa gerakan sosial adalah sebagai sebuah tindakan atau 
performance yang berkelanjutan secara bertahap, pertunjukan dan kampanye yang dilakukan oleh orang-orang bisaa dan mereka membuat tuntutan secara kolektif terhadap yang lain. Pada intinya dapat dikatakan bahwa gerakan sosial adalah sebuah kendaraan besar untuk orang-orang bisaa untuk berpartisipasi dalam publik politik. Menurut Tilly bahwa ada 3 elemen penting yang melekat pada gerakan sosial,sebagai berikut:

- Kampanye adalah sebuah pertahanan, organisir kekuatan publik dan membuat tuntutan kolektif pada target otoritas

- Seleksi gerakan sosial adalah kombinasi dari pekerja dari dan diantara pengikuti aksi partai politikb, menciptakan perkumpulan/asosiasi yanng bertujuan khusus dan koalisi,pertemuan umum, pertemuan formal, rapat umum, demostrasi, penyampaian petisi, pernyataan ke dan dalam media umum, dan selebaran.

Sedangkan menurut Sidney Tarrow, menyatakan bahwa gerakan sosial sebagai tantangan kolektif/bersama(kepada elit,otoritas,kelompok lain atau peraturan budaya) oleh orang-orang yang mempunyai tujuan yang umum dan solidaritas dalam interaksi yang berkesinambungan dengan elit,oposisi dan otoritas. Tarrow membedakan secara khusus gerakan sosial dari partai politik dan kelompok kepentingan.
Melihat hal tersebut, dapat dikatakan bahwa gerakan sosial bisa muncul sebagai akibat adanya ketidaknyamanan dari satu komunitas atau masyarakat terhadap situasi yang terjadi dalam kehidupannya. Mereka bereaksi secara spontan untuk menciptakan perubahan. Reaksi tersebut menjadi wajar terjadi manakala, pemerintah sebagai pihak yang memiliki otoritas tertinggi tiak mampu menjawab atas sebuah masalah yang terjadi.

Kondisi status quo ini seringkali memicu sebagian masyarakat untuk bertindak. Tindakan tersebut diantaranya dituangkan dalam bentuk gerakan sosial melalui media sosial. Seperti peristiwa yang saat ini sedang menghangat di media sosial atau di kalangan netizen tentang kasus rekaman pembicaraan antara Setya Novanto dkk dengan Pejabat Freeport. Manakala peristiwa itu dipandang masyarakat melukai hati nurani masyarakat dan pemerintah lamban bertindak, sebagian masyarakat menuangkan reaksinya melalui media sosial twitter \#papamintasaham.

Ini salah satu ilustrasi saja dalam menangkap fenomena gerakan sosial yang dilakukan melalui media sosial. Ilustrasi ini menunjukkan pula bahwa media sosial dapat menjadi potensi positif dalam membangun perubahan perilaku masyarakat. Potensi ini menjadi sebuah keunikan bagi sebagain orang untuk memanfaatkannya. Beberapa masyarakat menggunakannya dengan terorganisasi secara baik untuk membangun 
gerakan sosial dalam bentuk kepedulian sosial atas masalah yang terjadi di masyarakat.

Mengacu dari potensi positif yang dimiliki sosial media dalam implementasinya, maka gerakan sosial pun dapat memperkuat peran sosial media untuk menyuarakan berbagai hal. Mulai dari menyuarakan kesamaan rasa atas ekspresi ketidaknyaman dalam sebuah tatanan pemerintahan yang saat ini terjadi hingga sampai pada membangun kesepakatan membuat kegiatan nyata untuk merealisasikan gerakannya.

Bahkan sebagian lagi memanfaatkan media sosial untuk menggagas ide atau inovasi sosial yang bermanfaat bagi masyarakat banyak. Beberapa organisasi nirlaba memanfaatkannya melalui jejaring internet dalam melakukan penggalangan dananya. Dengan memunculkan proyek dan portofolio lembaganya, memungkinkan audience melihat kiprah lembaga dan bagi lembaga memungkinkan mendapatkan khalayak yang lebih luas. Artinya peluang donatur yang tidak terbatas.

Ini sangat mungkin terjadi mengingat tehnologi jejaring internet tidak mengenal batas wilayah. Selama jejaring tersebut terkoneksi ke seluruh lapisan dunia, seluas itu pula khalayak netizen dapat terjangkau. Voshel (2015) mengungkap:

\footnotetext{
${ }^{2}$ Elizabeth Harbeck Voshel, ACSW, LMSW. Sosial Media \& Sosial Work Ethics: Determining Best Practices in an Ambiguous RealityJournal of Sosial
}

The Internet today is ubiquitous. It has worked its way into every corner of our lives-including our professional practice-and it is here to stay. Technological advances have threatened our economic and personal security and these advances have changed the face of communication forever. ${ }^{2}$

Bahwa keberadaan internet adalah sebuah kemajuan teknologi yang tidak bisa kita hindari, maka apapun bisa dilakukan demi mencapai sebuah tujuan. Termasuk digunakan untuk menghubungkan sistem sumber dalam penggalangan dana untuk gerakan sosialnya.

\section{CROWDFUNDING}

SEBAGAI

PERUBAHAN ENERGI GOTONG

\section{ROYONG TERBARUKAN}

Pada tahun 2010 sampai dengan 2011 banyak lembaga bantuan layanan sosial yang terhambat dalam hal pendanaan, seperti contohnya fenomena Lembaga Bantuan Hukum (LBH) APIK dan Yayasan Pulih. Kedua lembaga pelayanan sosial ini merupakan lembaga pelayanan sosial yang bergerak dalam bidang Kekerasan Dalam Rumah Tangga (KDRT). LBH APIK dan Yayasan Pulih dalam tahun 2010-2011 hampir gulung tikar karena terhambat masalah dana. Menurut keterangan dari pengurus LBH APIK, hal ini bisa terjadi karena salah satu dari dua pendonor utama akan menyatakan mundur. 
Hal yang hampir serupa juga dialami oleh Yayasan Pulih. Yayasan Pulih bergerak dalam bidang KDRT dalam hal pemberian konseling. Ketika Yayasan Pulih memberikan layanannya, yayasan ini menentukan tarif sebesar Rp10.000,00 untuk konseling dan Rp 100.000,00 per kedatangan. Awalnya tarif ini dipasang untuk membantu biaya operasional dalam Yayasan Pulih, tapi pada akhirnya tarif yang dipasang ini pun tidak dapat membantu dalam pembiayaan operasional keseharian Yayasan Pulih dan Yayasan Pulih terancam gulung tikar.

Fenomena di atas memberikan fakta bahwa masih banyak lembaga pelayanan sosial dan organisasi nirlaba yang kurang maksimal dalam memberikan layanannya dikarenakan kesulitan dalam pembiayaan. Hambatan yang terjadi ini mencerminkan bahwa lembaga pelayanan tersebut kurang baik dalam manajemen lembaganya terutama dalam bidang penggalangan dana atau Fundraising. Kesinambungan organisasi, terutama kesinambungan keuangan kelembagaan, haruslah menjadi salah satu fokus perhatian utama. Dengan memperkuat keuangan kelembagaan, lembaga pelayanan sosial akan mampu bertahan dan berkembang sehingga program-program yang ada tetap terlaksana dan berkembang sesuai tuntutan dan kebutuhan masyarakat.

Lembaga pelayanan sosial nonpemerintah saat ini tidak bisa hanya berpangku tangan dalam melakukan penggalangan dana untuk lembaganya sendiri. Jika suatu lembaga terus hanya menunggu untuk mendapatkan donatur maka lembaga tersebut akan sama halnya dengan contoh dua lembaga pelayanan sosial di atas. Lembaga pelayanan sosial juga tidak bisa memakai 'label' pelayanan sosial untuk hanya mencari keuntungan saja dan tidak menjalankan fungsi dari lembaga pelayanan sosial itu sendiri. Padahal, Fundraising sangat dibutuhkan dalam suatu lembaga nirlaba atau lembaga sosial. Dari fakta yang diberikan di atas, permasalahan mengenai pendanaan tersebut disebabkan oleh kurang baiknya manajemen lembaga pelayanan sosial pada bidang Fundraising.

Salah satu alasan utama mengapa strategi pendanaan dilakukan adalah agar lembaga pelayanan sosial ini tidak mengalami ketergantungan kepada para donor utama. Menurut Said, Abidin dan Faizah (2003 : 34) secara umum ada tiga pola penggalangan dana yang dapat dilakukan oleh organisasi sosial, yaitu :

a) Penggalangan dana masyarakat dari sumber yang telah tersedia, baik dari perorangan, perusahaan maupun pemerintah. Strategi yang digunakan antara lain direct mail, membership, special event, endowment, dsb.

b) Penggalangan dana sosial masyarakat melalui sumber dana baru. Strategi yang digunakan adalah pembangunan unit-unit usaha yang menghasilkan pendapatan bagi lembaga (earned 
income), corporate fund, religious fund, traditional fund, charity boxes, arisan, media campaign, dsb.

c) Penggalangan dana sosial masyarakat melalui penciptaan sumber non financial. Strategi yang digunakan adalah sumbangan dalam bentuk in kind, kesukarelawanan, designated donation, dan sebagainya.

Beranjak dari realita organisasi pelayanan sosial, Fundraising menjadi penting bagi kelangsungan hidup. Situasi inilah yang mendorong beberapa lembaga pengelola danadana sosial untuk melakukan langkah strategis dengan menciptakan inovasi untuk menyerap dana-dana filantropi dari masyarakat. Karena itu beberapa lembaga sosial yang ingin melakukan langkah Fundraising dengan dukungan dari masyarakat tidak lagi semata melakukan aksi meminta sumbangan dengan mengetuk pintu dari rumah ke rumah. Sehingga tanpa sadar penggalangan dana tersebut hanyalah berfokus pada 'money oriented". Meskipun sesungguhnya kegiatan penggalangan dana (Fundraising) adalah berguna juga bagi kegiatan operasional lembaganya, namun tetap menjadi image yang tidak baik jika terfokus hanyalah untuk mengejar uang semata.

Dalam konteks definisi, Fundraising menurut Kementrian Sosial (2003) lebih melihat penggalangan dana ke arah sosial, penggalangan dana (Fundraising) adalah :

Upaya untuk menghimpun dana berupa uang atau barang dari masyarakat. Dana tersebut dimanfaatkan untuk menunjang pelaksanaan pembangunan bidang kesejahteraan sosial, mental, agama, kerohanian, kejasmanian, pendidikan, dan kebudayaan di kalangan masyarakat setempat. (dalam Winarno, 2010)

\section{Sementara Kim mengartikan Fundraising}

lebih dari sekedar mencari uang :

Menggalang dana adalah sebuah ilmu. Tetapi aturannya lebih seperti pelangi daripada sebuah rumus. Anda harus melukis dengan paduan warna dan perasaan yang halus. Dan, anda pasti sukses bila anda melukis dengan rasa kasih dan persahabatan. (dalam Norton, 2002:11)

Pernyataan ini merujuk pada sebuah strategi dan prinsip penggalangan dana. Dalam pernyataan Kim ini, ia menawarkan pula sebuah cara untuk melakukan kegiatan penggalangan dana. Karena buat Kim, kegiatan penggalangan dana perlu memiliki ilmu yang tidak hanya sekedar mencari dana.

Seperti diketahui, saat ini media sosial sudah menjadi bagian hidup masyarakat Indonesia. Sehingga membawa fenomena merebaknya penggalangan dana melalui jejaring. Aktifitas Fundraising melalui jejaring sosial inilah yang bisaa disebut dengan Crowdfunding. Crowdfunding merupakan suatu model pendanaan yang dengan beberapa aktor yang berperan didalamnya, yaitu pemilik 
proyek, lembaga Crowdfunding itu sendiri (situs online/media sosial), dan donatur. Crowdfunding itu sendiri sedang marak dilakukan oleh banyak lembaga sosial di Indonesia maupun internasional. Para pemilik proyek menggunakan internet khususnya media sosial untuk menjual proyek mereka kepada para donatur. Menurut Sullivan (2006), Crowdfunding adalah :

Crowdfunding inspired by crowdsourcing describes the collective cooperation, attention and trust by people who network and pool their money together, usually via the Internet, in order to support efforts initiated by other people or organizations. Crowdfunding occurs for any variety of purposes, from disaster relief to citizen journalism to artists seeking support from fans, to political campaigns.

Perhatian, kepercayaan, kerjasama kolektif, dan pengumpulan uang bersama merupakan 4 aspek penting dalam melakukan Crowdfunding. Keempat aspek ini saling berkaitan dan tidak bisa dipisahkan satu dengan yang lainnya. Dalam perhatian, pemilik proyek melakukan 'kampanye' supaya pemilik situs dan masyarakat memberikan perhatian kepada proyeknya. Setelah pemilik situs dan masyarakat memberikan perhatian, timbul kepercayaan yang ditanamkan oleh pemilik situs dan masyarakat kepada si pemilik proyek, untuk melakukan Crowdfunding bersama. Perhatian dan kepercayaan yang diberikan oleh pemilik situs menimbulkan sebuah kerjasama untuk melakukan pengumpulan uang bersama yang akan dilakukan oleh masyarakat.

Definisi Crowdfunding pertama kali dijelaskan oleh Sullivan (2006), namun sebenarnya istilah dan konsep Crowdfunding menurut Hemer (2011) diambil dari istilah serupa yang sudah lebih dulu dikenal luas, yaitu crowdsourcing, seperti pernyataannya berikut ini:

"The term Crowdfunding is derived
from the better known term
crowdsourcing, which describes the
process of outsourcing tasks to a large,
often anonymous number of
individuals, a crowd of people (here:
the Internet community) and drawing
on their assets, resources, knowledge
or expertise. In the case of
Crowdfunding, the objective is to
obtain money."

Ada satu perbedaan mendasar antara crowdsourcing dan crowdfunding ketika keduanya sama-sama menafaatkan media sosial dan internet sebagai perantara ke masyarakat luas. Perbedaan tersebut mengenai peran donatur yang mendonasikan uangnya ke suatu proyek. Crowdsourcing mengharapkan para donatur terlibat lebih dalam proyek yang dibantunya, dengan cara memberikan umpan balik berbentuk ide dan saran untuk keberlangsungan proyek. Berbeda dengan crowdsourcing, Crowdfunding hanya memanfaatkan para donatur untuk mengumpulkan dana demi terlaksananya suatu proyek. 
Crowdfunding sangat memanfaatkan situasi ini, dimana Crowdfunding bisaanya menggunakan internet untuk menggalang dana dari para pengguna internet dan media sosial. Para pemberi donatur bisaanya mempunyai tujuan dan visi yang sama dengan para individu atau organisasi yang memerlukan dukungan, contohnya adalah menolong korban bencana, dukungan fans kepada artisnya, dan untuk membantu melakukan pelayanan sosial kepada sesama.

Konsekuensi perubahan sosial yang terjadi sebagai akibat perkembangan jaman, ternyata berdampak pula pada pola kehidupan dan proses sosial dalam kehidupan bermasyarakat. Seiring dengan perkembangan teknologi media sosial, ternyata membawa pula pada struktur sosial baru dalam tatanan pergaulannya.

Senyampang dengan keinginan membangun relasi sosial, mereka memasuki era baru gaya berkomunikasi. Mobilitas tinggi menjadi alasan kuat untuk mencari cara berkomunikasi yang instan. Seharusnya pula beberapa organisasi sosial dapat 'membaca' situasi tersebut untuk menarik simpatinya. Karena bukan tidak mungkin semangat kegotongroyongan di lingkup komunitas netizen masih ada dan membara. Hal yang tidak bisa kita pungkiri adalah pengaruh teknologi membawa manusia maupun masyarakat menuju pada era sosial media. Untuk sebagian masyarakat sosial media digunakan untuk membangun jejaring bisnis, sebagian lagi digunakan hanya untuk sekedar berinteraksi dengan individu lainnya. Namun ada juga sebagian masyarakat yang benarbenar memanfaatkannya untuk tujuan mulia. Seperti contoh dua fenomena pada tahun 2009-2010 yang sudah menggunakan cara 'patungan' dalam mendapatkan uang melalui sosial media. Kasus pertama adalah kasus yang menimpa Prita, dimana ia dilaporkan oleh sebuah rumah sakit swasta karena dituduh mencemarkan nama baik rumah sakit tersebut. Kasus kedua adalah kasus kesehatan yang menimpa Bilqis Anindya Passa, balita berumur 17 bulan ini mengalami penyakit kegagalan fungsi saluran empedu. Kedua kasus ini mengharuskan Prita dan kedua orangtua Bilqis mengeluarkan uang dalam jumlah yang banyak. Ketidakadlian yang dialami oleh Prita dan rasa kemanusiaan untuk Bilqis membuat masyarakat tergerak untuk membantu mereka. Awalnya pihak dari Prita dan orangtua Bilqis menggunakan situs media sosial facebook untuk memulai aksi mereka dalam mengumpulkan uang.

Selain itu, salah satu platform Crowdfunding pertama di Indonesia diantaranya adalah Kitabisa.com. Situs ini berada di bawah bimbingan Rumah Perubahan milik Rhenald Kasali. Kitabisa.com merupakan Crowdfunding sosial pertama di Indonesia. Kitabisa mengedepankan konsep kolaborasi sosial, yaitu keyakinan bahwa untuk membuat sebuah perubahan besar, setiap orang harus bergabung dan berkontribusi 
dengan bantuan apapun yang bisa mereka berikan. Setiap orang dapat memulai kontribusi mereka dengan membuat akun di Kitabisa.com. Orang-orang yang memiliki ide dan proyek kreatif di bidang sosial dapat mendaftarkan ide mereka di website Kitabisa.com. Pada saat mendaftarkan ide, mereka harus menceritakan latar belakang, tujuan, tempat dan waktu pelaksanaan, serta jumlah dana yang dibutuhkan untuk membuat ide mereka menjadi nyata.

Proyek yang telah lolos kurasi akan diposting di website kitabisa.com. Masyarakat dapat memberi dukungan terhadap ide-ide sosial tersebut dengan memberi donasi berupa uang dengan jumlah yang tidak ditentukan. Dalam Crowdfunding, hal yang paling penting bukanlah jumlah donasi per orang, melainkan jumlah orang yang berpartisipasi, karena itulah kekuatan konsep ini ada pada crowd. Sebagai ilustrasi, jika setiap orang berdonasi $\mathrm{Rp}$ 100.000 saja, namun jumlah yang berdonasi ada 1000 orang, maka dana yang terkumpul menjadi Rp 100.000.000. Semangat kebersamaan mengubah hal kecil menjadi sebuah kekuatan yang besar. Fakta tersebut yang mendasari optimisme kitabisa.com bahwa Indonesia bisa bangkit dengan kolaborasi dan kerjasama banyak orang.

Semangat kolaborasi tersebut pada dasarnya merupakan semangat yang sudah menjadi budaya nusantara, yaitu semangat gotong royong. Semangat dimana setiap orang mau turun tangan membantu dengan apapun yang mereka punya. Selain donasi berupa uang, kontribusi lain yang dapat diberikan pada sebuah proyek sosial di kitabisa.com adalah dengan terjun langsung menjadi relawan, atau menyebarkan dukungan terhadap proyek tersebut melalui jejaring sosial. Semakin luas proyek tersebut tersebar melalui jejaring sosial, maka semakin banyak dukungan yang didapat, dan semakin banyak pula orang yang dapat berkolaborasi. Sebagai salah satu inovasi baru dalam pergerakan sosial di Indonesia, gerakan Kitabisa didukung oleh berbagai figur publik seperti Dian Sastro, Andy F. Noya, Pandji, dan Oki Setiana Dewi dari kalangan artis, serta Faisal Basri, Babe Idin, dan Masril Koto dari kalangan tokoh masyarakat yang bergerak di bidang sosial. Mereka mengkampanyekan ide kolaborasi sosial melalui video di Youtube. Sejak pertama kali diperkenalkan pada pertengahan tahun 2013, Kitabisa.com telah meluncurkan 8 proyek sosial yang mendorong pengembangan sosial di berbagai bidang seperti pendidikan anak jalanan, industri kreatif, hingga usaha rakyat. Dua diantaranya - Parcel Nalacity dan Wakaf Al-Qur'an, bahkan telah mendapatkan pendanaan melebihi target dan berhasil dijalankan berkat dukungan masyarakat.

Hal tersebut menjadi bukti, bahwa inovasi kitabisa.com dalam menghubungkan inisiatif sosial dan masyarakat melalui teknologi informasi dapat membawa semangat gotong royong Indonesia pada level yang lebih tinggi. Semangat yang dibawa Kitabisa.com 
diharapkan mampu terus mendorong Indonesia ke arah yang lebih baik, dengan menciptakan perubahan dan menghubungkan kebaikan.

(http://news.indonesiakreatif.net/menghubung kan-kebaikan-lewat-kitabisa-co-id/.diunduh pada tanggal 8 mei 2015, puku 20.30 WIB)

Melihat hal tersebut, disadari atau tidak perubahan pola interaksi ini membawa pada perubahan sistem sosial yang terjadi meski hanya sekedar cara berkomunikasi. Jika melihat kembali pada akar konsep kegotongroyongan adalah usaha sukarela dan bergerak tanpa pamrih, dengan pola komunikasi yang berubah membuktikan semangat kegotongroyongan masih ada.

Bahkan potensi ini sejatinya dapat menjadi sebuah strategi baru bagi organisasi nirlaba atau organisasi pelayanan sosial dalam membangun jejaring khalayak yang lebih luas. Demikian juga halnya dengan peran pekerja sosial , dapat dikembangkan dengan memanfaat media sosial yang ada. Seperti yang dinyatakan Voshel (2015):

The sosial work profession needs to revise its standards of practice accordingly to meet the challenges presented by our changing world. This means expanding the way we think about sosial work ethics to include online sosial media. Sosial media requires that sosial workers reframe how they think about privacy, confidentiality, professional boundaries, and has challenged us to innovate with new, ethically sound ways to serve our clients and constituents. ${ }^{3}$

\section{PENUTUP}

Sebagai wujud kekinian, konsekuensi perubahan sosial dalam konsep gotong royong ternyata bermetamorforsis dalam media yang berbeda. Esensi gotong royong sebagai tindakan bekerja sama tanpa pamrih tetap tidak hilang. Namun berubah dengan menggunakan cara yang berbeda. Artinya kepedulian seseorang atas sebuah musibah yang menimpa individu lain tetap ada, bahkan bisa menjadi energi yang besar manakala media sosial bergerak lebih luas lagi.

Wujud kolaborasi yang dilakukan oleh Kitabisa.com adalah sebuah pembuktian dari adanya inisiatif masyarakat dalam memecahkan masalah sosial. Melalui gerakan sosialnya, kitabisa.com mengelaborasikan kepedulian masyarakat dengan membuat kegiatan Croowdfunding. Sehingga hal ini dapat diartikan bahwa teknologi media sosial ternyata dapat dimanfaatkan secara potensial atas kesulitan dalam mengatasi masalah dana bagi lembaga sosial.

\section{Daftar Pustaka}

Abidin, H., \& Kurniawati. 2004. Galang dana ala media: Strategi Efektif Mengumpulkan Sumbangan Masyarakat. Jakarta: Piramedia.

Parsons, Talcott. 1951. The Sosial System. New York : Amerind Publishing Co. Pvt. Ltd

\footnotetext{
${ }^{3}$ Ibid hal 8
} 
Kottler \& Andreasen.1995. Strategi Pemasaran Untuk Organisasi Nirlaba.Gajah Mada University Press. Yogyakarta

Lawang, Robert, M. Z. 2005. Kapital sosial:

Dalam Perspektif Sosiologi Suatu Pengantar.

Depok: FISIP UI Press

Norton, Michael. 2002. Menggalang Dana : Penunutun Bagi Lembaga Swadaya Masyarakat dan Organisasi Sukarela di Negara-negara Selatan (Masri Maris, Penerjemah). Jakarta : Yayasan Obor Indonesia.

Norton, M. \& Culshaw, M. 20000. Getting

Started In Fundraising. New Delhi : Sage

Publication India

Quebral, M. Terol, \& Roman, F. 2002. Asia Pasific Philantrophy Consortium : Investing In Our Selves: Giving Fundraising In Asia. Fundraising in Asia. Philippine : Asian Development Bank.

Saidi, Z., \& Hamid, A., \& Faizah, N. 2003. Pola dan Strategi Penggalangan Dana Sosial di Indonesia: Pengalaman Delapan Belas Lembaga Sosial. Jakarta: Piramedia

Soekanto, Soerjono. 1994.Sosiologi Suatu Pengantar. Jakarta: Raja Grafindo Persada,

Wibawa, Budi, Meilany, \& Santoso. 2010. Dasar-dasar Pekerjaan Sosial. Bandung : Widya Padjadjaran.
Widjajanti, Darwina. 2006. Rencana Strategis Fundraising. Depok : Piramedia

Wolf, Thomas. 1990. Managing c Nonprofit Organization. New York : Prentie Hall Press

Young J., \& Wyman, K., \& Swaigen, J. 2007. Menggalang Dana Untuk Organisasi Nirlaba (Lensi Mursida, Penerjemah). Jakarta : PT. Ina Publikatama

\section{$\underline{\text { Sumber Lain }}$}

Achsannanda Maulyta Sari ,2015. Artikel. Menegakkan Tradisi Kerja Bakti Sebagai Bentuk Revitalisasi Nilai Gotong Royong, Departemen Pendidikan Sastra Jepang ,Universitas Airlangga

Elizabeth Harbeck Voshel, ACSW, LMSW. Sosial Media \& Sosial Work Ethics: Determining Best Practices in an Ambiguous Reality. Journal of Sosial Work Values \& Ethics, Spring 2015, Vol. 12,

Hemer, Joachim. 2011. A snapshot on crowdfunding. Karlsruhe: Franhoufer ISI. 10 Juli 2014.

www.instink.co.id. diunduh pada tanggal 9 Mei 2015 pukul 18.45 